\title{
THE ROLE AND MOTIVATION OF A TEACHERS IN THE TEACHING AND LEARNING PROCESS CASE STUDY AT THE TECHNICAL HIGH SCHOOLS, VOCATIONAL GROUP OF INDUSTRY (THSV-GI) BECORA-DILI, TIMOR-LESTE
}

\author{
*Tome Valente Tilman
}

\author{
Graduate Student Master of Public Administration, Universidade da Paz, Dili-Timor-Leste
}

\section{ARTICLE INFO}

\section{Article History:}

Received $01^{\text {st }}$ February, 2021

Received in revised form

$11^{\text {th }}$ March, 2021

Accepted 26 ${ }^{\text {th }}$ April, 2021

Published online $30^{\text {th }}$ May, 2021

\section{Key Words:}

Teacher duties, Motivation study, Method, Quality of Teaching and Learning Process.

\begin{abstract}
This thesis is entitled, "The Role and Motivation of a Teacher in the Teaching and Learning Process with a Case Study at the technical high schools, vocational group of industry (THSV-GI) becora-dili,". The purpose of this study was to find out how the teaching duties and learning motivation of the THSV-GI Becora-Dili Industrial Vocational School students during the teaching and learning process and improving the quality of student learning. References from various articles, the internet, as well as some information from all informants (interviewers) were used in this study to increase the knowledge of the author in writing this thesis. The author uses qualitative research methods to describe the results of research to determine the importance of a teacher's task and learning motivation for students of the Technical high schools, vocational group of industry (THSV-GI) Becora-Dili, during the learning and learning process. Regarding the learning process in this study there were six (6) respondents. The instruments used in data collection were; observation, interview, documentation and researchers use six question indicators to interview directly. From the results of the existing research, the researcher concluded that the task of a teacher and learning motivation for students of the THSV-GI BecoraDili Industrial Group during the teaching and learning process is very important because students can further improve their abilities. Their independent learning about the learning given by the teacher with different methods, they can get good grades and as qualified students about engineering.
\end{abstract}

*Corresponding author:

Tome Valente Tilman

Copyright $@$ 2021, Tome Valente Tilman. This is an open access article distributed under the Creative Commons Attribution License, which permits unrestricted use, distribution, and reproduction in any medium, provided the original work is properly cited.

Citation: Tome Valente Tilman. 2021. "The role and motivation of teachers in the learning process case study in technical high schools vocational-group of industry, estv-gti becora-dili)", International Journal of Development Research, 11, (05), 47106-47115.

\section{INTRODUCTION}

Education is very important in today's world, through modern education, all countries care about the human resources they have to build their country well. In the current era of modernization, all countries have the ambition to be winners in terms of education, and competition for the quality of education human resources in each country is a benchmark for other countries, and the quality of education is one of the country's main programs for the progress of a country, and human resources. quality is needed to achieve the goals of a country and the world. As it is the only national independence in recent years, education is very limited compared to other countries, there is also one of the highest ambitions in this modernization era to compete with other countries in various fields based on the needs of the state as contained in the Constitution of Timor-Leste article 59 on (Education and Culture) in line with 1, It should be noted that; The state must recognize and guarantee the right of all citizens to education and culture, as wellthe establishment of a universal, compulsory and free basic education system, as required by law.
To ensure the quality of education, the Government must pay more attention to all sectors, especially the Ministry of Education, which is the highest responsible agency for education. To achieve market competition, the country will provide a more detailed motivation in the areas of education, health, and technical training for young people (particularly students) in the area of expertise to promote the capacity of the labor market. Base on Diploma Ministerial 22/2016 de 9 de março que discute a transferência de Escolas Públicas para Escolas tecnico vocasional, Because according to the fact, when students, technical and vocational high schools complete their education at the technical high school level, some individuals are immediately allowed to compete in the labor market. Vocational Technical High School-Industrial Group, THSV-GI Becora-Dili is also a technical school which has produced a large number of students and it turns out that many people have a job market opportunity to continue to improve their daily life. According to Harris in Slamet (1992: 2) means that technical high schools are schools that provide employment for the community (especially students) according to their abilities or knowledge, as well as the type of work desired to support their lives in the future. As a technical school which is also a 
pilot school for all technical schools in Timor-Leste, the Ministry of Education needs maximum attention or support from the Ministry of Education regarding the learning process (both theoretically and practically) so that it can become students in the future. The learning process at the THSV-GI BECORA DILI Industrial Group Vocational Engineering College has two types of activities, namely the theoretical learning process which is often carried out in the theory room, as well as the learning process carried out in the classroom and the learning process carried out in the classroom or routine student workshops, as well as activities laboratory, carried out in their respective majors. During practical and theoretical learning, there are several challenges that become obstacles to the role of a teacher; Some teachers have played a role as teachers in using school facilities properly and some teachers have not provided maximum motivation to students to foster enthusiasm for learning in students. This means that the role of the teacher in the learning process is also an indicator of the quality of student learning that is taking place at the THSV-GI BECOURRA Vocaçional-Grupo Technology Technical High School because in this process the teachers have used good models for students and theories. Prihatin Eka (2008: 57) said that the group has not; "In the teaching and learning process, teachers try to encourage, guide and provide learning facilities for students to achieve goals."

Nuni Yusvavera Syatra, (2013: 7) say that; "Teachers have an important role to play in directing their students in school." That is, the role of the teacher to guide people in school. There are also some challenges faced by a teacher, such as curriculum (teaching hours) and teacher facilities (many Korean languages make it difficult for teachers to explain more clearly to students) Teacher motivation in Vocational High Schools, Industry Group THSV-GI, it is very important for students to improve the quality of student knowledge in the teaching and learning process (both practice and theory) because good motivation for students will also produce better learning outcomes and students. Challenges, there is often motivation accompanied by practical activities in workshops. According to Sharspear's policy, (1990: 75-76) it says that: "In learning activities, roles and motivation lead to learning activities, to ensure the continuity of teaching and learning activities, so that the desired learning objectives can be achieved .."

This means that there is a strong influence on the learning process because good motivations will result in good study results. To better understand the above challenges, by identifying the problems that will mean that the identification of problems is a more important research process when compared to other processes in research, as it is possible for the identification of problems to be defined as research or not possible for these problems. According to Tahir $(2011 ; 19)$ said that "Identification of the actual problem is carried out to find the scope of a particular problem within the scope of the problem, then one of the problems is selected according to the ability of the researcher both in terms of implementation or curricula." This means that the proper identification of problems will be the subject of the scope of the problem and the problem will be chosen as an indicator of the research carried out by the researchers' knowledge. Based on the aforementioned explanation, problems were raised at the Technical High Schools of Tétum, the Industry Technology THSVGI BECORA DILI from the following one;

- $\quad$ Students need the best method of teaching.

- Students need a high-quality workshop facility.

- Students need maximum motivation from teachers.

- Teachers must act as professional teachers.

- Teachers and students need curricula (add more hours of teaching) that are maximum on a scheduled basis.

The formulation of the problem: Based on the above background explanation write the owner on how to formulate the problem, how can the role and motivation of the teacher in the learning process?

The Objective Research: The purpose of the research outlined by the owner means that they achieve the results through one or another means that to respond to the formulation of the problems that have been formulated.

Scope and Constraints: That the scope and limitations of the problem have been chosen through identifying problems. This problem will therefore be limited to specific circumstances when we observe the issue of written ownership (researchers) more focused on the way it is going to go and how it will be carried out with the next action.

Problem Limitation: The limitations of this research were limited to teachers and students who have carried out their learning activities in the academic year 2019-2020 at the Technical High School of Tétum (GVTI) BECORA DILI.

\section{LITERATURE REVIEW}

Fundamental Theory: In this chapter, the owner wrote a detailed explanation of the title "The Role and Motivation of Teachers in the Learning Process" which supports the ideas or arguments of the intellectuals to further strengthen the research views within that research.

Definition of Teacher: When we talk about the role of the teacher in education, in the context of education itself has an important element that doesn't outside of education is the teacher. The teacher has a role that means to train his/her people in school. There are also some ideas from the master regarding the role of the teacher as follows:

According to Poerwadinta's knowledge (1996), the teacher's role is to play teachers who teach people (students) to participate in the formal school process to achieve a goal. Mulyasa (2007:37) raised their thoughts by identifying the role of the teachers; Meanwhile, teachers as educators, as instructors, as instructors, teachers as foremen, teachers as administrators, teachers as community members, masters as administrators, as development instructors, teachers as innovators, teachers as evaluators. Through these roles, we suggest that a teacher who has professional knowledge and professions is the only and quality of teaching. On the other hand, a teacher who is a professional can also perform his or her duties and functions in a ma imum manner according to his/her experience and according to his/her profession based on the study that he has learned.

The role of the Teacher: When we talk about the role of teachers means that we speak about; sympathy, concerns, presence, survival as well as individual or group involvement with spontaneous or program. With the general definition of the teacher's functions, the owner must take some definition of the following knowledge; According to the excellency of the Indonesian High Language Lab (1996:75), it is stated that the word of the teacher's role in their primary definition is as part of the main actors involved in the activities to achieve a proper goal. For example, someone who is the actor in a film will play correctly during the film process from opening to closing, and he will follow the behavior and instruction to give his/her satisfying result to his promoters and clients. According to Russia (1989:33), the role of the teachers is a unit of action that an individual or individual has made to a group from the minimum to maximum end with good results and according to the standard of instruction. Based on the ideas above, as written by the owner concluded that the intention, means, or important values of the role of the teacher is that the second parent of the student who has carried out the action and strategies to show or implement them in a variety of activities, both within the curative and extracurricular programs for students to be satisfied with everyone.

The Motivation of teacher: The design of the study was intended and the objective of the study was to benefit from the study process. Some students have had problems in the study process so that they can influence the results of the study not as much as possible. To respond to the problems of learning through motivating 
factors re-examining the students' study objectives (Puasari Hospital, 2012).

According to Clayton Alderfer (Hamdhu 2011) said; "Motivation to learn is the tendency of students to carry out all learning activities driven by the desire to achieve the best possible achievement or learning outcomes."

This means that the motivation for the study is the intention of the students that carry out the study activities to obtain the maximum delivery of the study results.

The proposal was according to the wisdom of M. Ngalim Purwanto, 2 $007: 71$ ) reminds us that motivation is the intention of someone who gives influence to himself so that he can do something as he wants. Through the aforementioned definitions, the owner concludes that the motive behind which an individual force was intended to force him or herself to do something to achieve a goal at a time when he was dominating himself or herself or herself.

\section{The Type of Motivation Study}

In terms of the definitions of masters knowledge there are some insights from psychology such as; By the knowledge of Ngalim Purwanto, (2007:64) it says that there are three main reasons:

- The need for a body that is directly related to the body of the person is hunger, thirst, sleeping, patience, and others.

- The motive for the present reason is that this reason is not the result of ourselves but also others; the reason to keep away from the enemy, the reason to avoid the misdemeanors' challenges.

- This means that one reason is reported to a target.

Furthermore, Sartain wisdom was cited by M. Ngalim Purwanto, (2007:62) divided the motives for the two parties:

- Psychological Drive Drive means that there are grounds for psychological attitudes. Ex: eat, drink, etc.

- Social Motive means that a reason to have a relation with another person in society

There are also types of teaching motivations in schools that are divided into both parts: Motivation of doctrine and Disobedience

\section{The Function of the motivation Study}

According to hikmah (2005: 189), the role of motivation in human development as in South Sudan (2005: 189) defines the role and motivation that grows within as follows;

- Forcing people to make motivation as a penetrating machine that requires energy to encourage people to carry out certain activities.

- Becoming a timeline means that determining which objectives are to be known. In this way, the motivation may be to provide mandatory activity to formulate the intended objectives.

- Selection of progress means that, eliminating any conduct that does not benefit from the objective.

In addition, other functions can be influenced by what they will receive, since this concept of motivation relates to the delivery and results of the study. Teachers within a learning process are motivated by the students.

Definition of Learning Process: This learning process is a challenging activity because it is full of the students who want to learn and the teachers as teaching. In this process, we can also call on the process of transferring sciences and experiences from teachers to students so that they can be a reference for students at present and in the future. There is also the knowledge that strengthens this definition with their ideas, arguments, and ideas relating to the learning process, as follows;

According to the National Dictionary of Tetum, the first edition. The National Linguistic Institute of UNTL (2005:42) states that: "The learning process is behavior or learning activities."

According to Slamet (2003:2), it says: Learning is an effort or process that a person is doing to change the behavior that is more than the experience and, through interaction with the community. According to Purwanto (2003:84), this learning has each person and the learning process takes time for a person or a student to be mature. The learning process is the most complete, as there is an accumulation between teachers and students to complement each other in situations. According to Nana Surjana (1989:7), it says: The process of transformation in each individual is the result of a learning process carried out by various forms or types such as changes in intellectual knowledge, understanding, attitudes, skills, procedures, and changes in all aspects of studies. In regards to the thinking of the masters, the reader will shorten that the study or learning is the process of transformation and change in the individual. When all studies are conducted there is no change in the person's self-esteem, it appears that there is no learning process that happens to that person. Change is the result of the study process that can be seen as a relative form of permanent nature, such as changes in the lack of knowledge of the profound knowledge, from which it is not possible, from one presenting herself badly to a proper and more adequate way. These changes are caused by the effects of interaction with a surrounding environment. Besides the tax change process or the maturity of the state. In addition, these changes have permanent, mutual, and safe duration, not just a temporary occurrence.

Difference to Learning methods: The learning method has several different methods spoken by Hamdani (2011:83), as follows: (Lecture, Discussion, Question and Answer, Group discussion, Demonstration and Experiment, Study task and recitation, Group Work, Role Playing, Problem Solving, Team System, Field Trip / Field Trip, Human Resources, Community Survey, Simulation, Case Study, Tutorial, Brainstorming, Free Study, Group without a Leader, Exercise, Emphasis Exercise.

From the different methods above, the reader can choose the method of solving the problem by Hamdani (2011:85) for the following reasons:

- Use of the problem resolution method, students study more actively in resolving the problem.

- Using the problem resolution method, students do not defend what is reported by the teacher but can try to resolve their own them.

- Use of the problem resolution method, as well as using a lecture and discussion method.

- The students were maybe responsible for what they have taught.

As the expert members think about the learning process, it is written that when the learning process is going well, the teacher strategy must be organized hours on the way, managing the class, and so on. Therefore, the students could not feel sluggish, feeling sleepy, and return home early but were eager to attend the learning process and finish.

The Learning Activity: Teaching and learning activities are formal activities that occur in schools and are in accordance with the school's internal regulations and the educational curriculum. Teaching and learning activities at Vocational High School-Grupo Tecnologia Indústria THSV-GI BECORA DILI take place in two parts, namely the theoretical learning process, the activities carried out in this process, the majority of the material or lessons in the civil department and the practical learning process carried out in each department conducted by a teacher from the department. some ideas coming from experts to further strengthen this process; 
Also, the learning process itself has several aspects from Turney's knowledge (2005:78) underline that:

- Using creativity ask questions

- Give strength, pay attention to certain behaviors.

- Make variations in the learning process.

- A good explanation of the situation is correct and is based on reality

The time of commencement of the lesson and the closing of the material is Follow a small group discussion to share the students with a variety of interactions to summarize the matter Organize the class, to create a learning environment well.

The explanation above gives us the writing of the reader to clarify that the teacher has an important role in the learning process. The students are mandatory under the teacher's role in helping them in developing the skills and optimizing the talent and capacity of the students. There is no teacher role, it is difficult for students to achieve optimal living goals. A student has a change in total and will be successful when interpreting teachers, family, and society.

Conceptual Framework: The role and motivation of the teachers in the learning process is a direct action carried out between teachers and students to achieve a good goal, such as the darkness for the light, has not yet been known and others based on the student environment. As well as the theory of Uma Sekaran (1992) in Sugiyono (2011) said; "The frame of mind is a conceptual model of how the theory relates to various factors that have been identified as important, thus it can be said that the frame of mind is an understanding that underlies other understandings, a fundamental understanding and becomes the foundation for every thought or thought. a form of the process of research to be carried out. "This means that the conceptual framework is a conceptual model that describes how theories to other factors are identified as a conceptual framework that is a basic knowledge within the research process through the role and motivation of the teacher to increase the quality of study in the learning process.

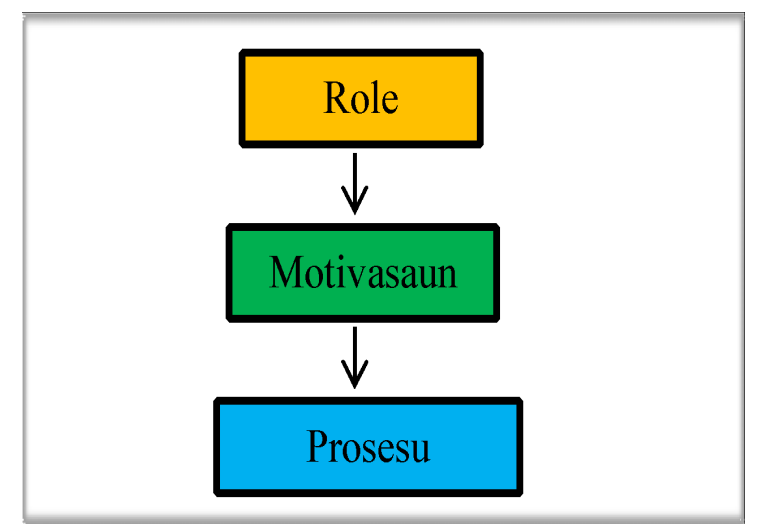

Clarification of the conceptual framework above is as follows;

- The role of teachers in this research means that they are the role or role of the formal education profession responsible for teachers and are also a precursor to teachers in delivering and showing them to students throughout the learning process to achieve better results in the assessment of their delivery.

- The motivation of a teacher in this study is the intention to motivate a student in the learning process, to create the will and enthusiasm for student learning during the learning process and also after the learning process in order to achieve its goals in the future.

- The teaching and learning process is a complex formal activity in schools because it contains teachers and students to carry out the process of transferring knowledge, experience through teaching. During this process, teachers, and students, like students will work together to achieve goals.

\section{RESEARCH METHODOLOGY}

In this research methodology, the owner is using qualitative research methods. According to Tohirin knowledge (2013:2), the qualitative research method is research used to develop owner and informants' views through words in the interview process. According to the aforementioned knowledge, Afifuddin (2009:57), the qualitative research methods are used to research the nature of the research, writing owners (researchers) are instrumental, data collection techniques, data analysis and inductive research results, and qualitative research results are running into general terms. Based on the above knowledge, the owner said that the research method was used by the owner to research to obtain data, collect data, develop data, and final result from the survey. To benefit this thesis, entitled "The Role and Motivation of Teachers in the learning process" (Case Study in the Technical High School of Tétum Vocational-Grupo Tecnologia e Indústria Becora, Dili, Academic Year 2019-2020).

\section{Approach and Type of Research}

Approach: A technical approach is an idea or thought derived from writing owners to approach information in the research process based on the research title. According to Syaifudin Sagala (2005:68), it says that techniques are a method used to achieve the instructional objectives. On the other hand, Nurma (2009:1) said that an approach that focuses on strategies and plans to achieve the objectives.

The Type of Research: The types of research outlined are qualitative types of research. Similarly, according to the aforementioned knowledge the Punaji Setyosari (2012:39); "Descriptive qualitative approach, which aims to explain or describe a situation, event, object whether people or everything related to research."

Population: Individuals who are generally included in all objects and projects that have realistic and quality characteristics as determined by the researchers to carry out the study and result of the survey (Sugiyono, 2012:119). In this research, all entities included teachers, students, and administrative staff of THSV-GIDILI.

Sample: The objective or Sample for this research is to be the resources of the survey where information is obtained. The writer (researcher) took the following objects: Director of Schools, Vice Director, Deputy Director of Curriculum Affairs, Estdaniutil, Master/a da Turma, Teacher/Material

Data Collection Technical: The collection techniques were the main and most important step in this research, according to Sugiyono knowledge (2009:224) stated that data collection techniques were a strategic step forward in the research because the main objective of the research was to be collected is to give data in nature. (natural conditions), information is the first or real data source that comes from the research area directly through observation techniques, interviews and documentation techniques (primary data), and data collection techniques such as Technical observations, interviews, and documentation techniques. Research steps were taken by researchers to use the qualitative research chart on verification and data findings following Miles \& Hubermen (1992:15).

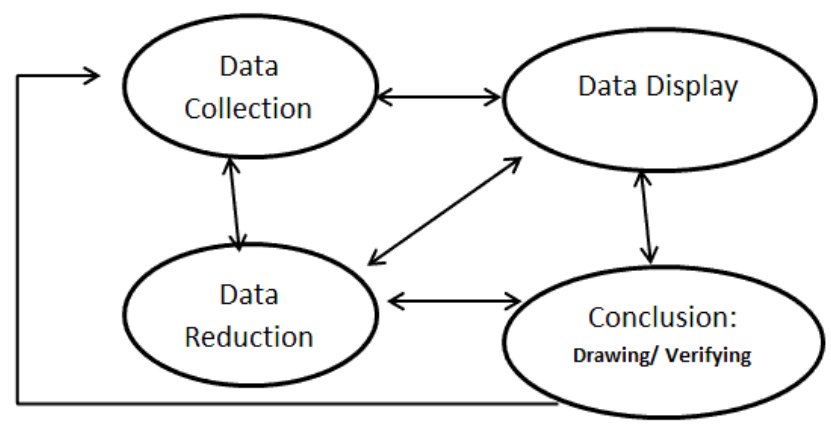


With the above criteria, the process of title research was conducted correctly and no inventory of the data was found. Based on the aforementioned definitions, the reader concluded that, after collecting data from the research in a manner or method, as written by the owner (researchers) use qualitative methods to analyze these data, and not using quantitative methods.

\section{RESULT AND DISCUSSION}

Brief profile of School: Escola Secundária Vocacional-Grupo Tecnologia Indústria THSV-GI BECORA DILI is located in Becora Village, Cristo-Rei District, Dili Municipality. This school was founded during the Indonesian occupation in 1986 and began in the 1989 academic year under the name STM Negeri Dili (SM2), the Governor of the Governor. Mário Viegas Carrascalão. Escola Secundária Vocasional-Grupo Tecnologia Indústria THSV-GI BECORA DILI as Technical High School Public High School, which reactivated their learning activities from 01 July 2000 until now. Rehabilitation and facilities originating from the Korean Government are determining factors for teachers and students in the learning process at the THSV-GI BECORA DILI Industrial Technology Vocational High School because these facilities are a guideline for teachers and facilities as well. a source of funding for all students to continue their studies at university or to compete in the labor market. In everyday life Escola Secundária Técnica Vocational-Grupo Tecnolina Indústria THSV-GI BECORA DILI respectively: Department of Civil Construction, Department of Electricity and Electronics, Department of Energy, Department of Information Management and Procurement Department, each of these departments along with their workshops and laboratories so that students can access practical training, technical support in normative, adaptive, and optional terms as general material for all majors and social work that sends the three students to attend. training in the community (both private companies and state institutions) for two months, to implement or apply knowledge through practices learned during school.

\section{RESEARCH RESULTS}

Regarding the results of the research, written surveys and direct interview methods with respondents through question and answer sessions, the researcher asked respondents directly to the school directors, teachers and industrial staff, ESTV -GTI, Dili. Then explain the identity of the respondent based on the respondent's knowledge of the problem that occurred and identify information from the respondent to analyze the data qualitatively and the instruments used by the researcher in conducting interviews with the teacher's strategy in the learning process that has an impact on students. effects and solutions to ensure the success, goals, and expectations of students who are ideal for human life in everyday life. In this interview, it was conducted by a researcher in the Organic Structure of the Technical Middle School of Vocational High SchoolGrupo Industrial Technology, THSV-GIBecora-Dili. Based on the roles and responsibilities mentioned above, it becomes a source of researchers to understand what is useful in the school and the various positions mentioned above are also research samples and using qualitative or inductive research methods does not mean quantitative research but qualitative research.

Where for the first time with the School Director, Mr. Francisco Gutterres L.CG.

Do you think the role and motivation of a teacher is important to students?

"The role and motivation of a teacher for students is very important, because as a teacher in educating there must be a role and motivation for students through the methods used to motivate students in the teaching and learning process and outside of school. In the environment, student motivation is one way to motivate students to follow the internal and external regulations in ESTV-GBETI.
There are also some student motivations including; is a learning process in the classroom, through peer-to-peer approaches, through internal school regulations, through mutual respect and others.". Source (Interview on Monday, 19 October 2020)

What motivates students to be diligent in the teaching and learning process?

"Student learning motivation in the teaching and learning process goes well because teachers and students collaborate in the intended teaching and learning process, and students are committed to participating and hearing about what the teacher says about science and technology to be understood. Student motivation is also important because as a teacher it is necessary to set criteria for students to understand the characteristics of each student in the class or also through practical activities, training, formal education, because after all they are a teacher. THSV-GIBECORA DILI, which wants to prepare individual or professional human resources with abilities, skills, personalities, and responsibilities to society.". Source (Interview on Monday, 19 October 2020)

\section{What is the teaching management process in the classroom?}

"The learning management process in the classroom is focused on the punctuality or discipline of teachers in the classroom and controlling the student learning process. The management of teaching in the classroom is based on lesson plans that guide students and teachers, so that teachers can teach according to the curriculum available on ESTV-GBECORA, DILI. The learning process that is successful in the classroom is by controlling student discipline and managing class management, how students can accept subjects and learn what is taught by the teacher in the classroom. Several indicators are used for the management process in the classroom, namely; Explanation, Asking Student Understanding, Giving time for student feedback, Problems, Discussions, Practices, Based on the hours that have been allocated based on the curriculum and lesson plans.

\section{Source (Interview on Monday, 19 October 2020)}

What methods are used in the teaching and learning process?

"There are various methods used by a teacher in the teaching and learning process, namely; (share teacher experiences) how to use methods that can help students to understand and achieve their goals in learning. Some of the methods that are always used in the learning process are the methods of writing, reading, explaining, discussing material, delivering theoretically and practicing.". Source (Interview on Monday, 19 October 2020)

In your opinion, as a teacher, how is the learning process in class or at workshops?

My observations about the learning process are good because the teacher uses a variety of methods to teach students. As for several facilities that provide maximum support in the learning process, as follows:

- $\quad$ Prioritize computer use and projects in the theory space.

- The Korean language course one of the Korean volunteer teachers was assigned to a Korean language teacher to increase their knowledge of Korean, because many facilities use Korean.

- Creating an excellent educational environment to enable teachers to empower themselves to better serve students in the teaching and learning process.".

Source (Interview on Monday, 19 October 2020)

What do your motivations look like to students in class or in workshops?

"The Motivation of studies for students in the classroom is important because it can help the learning process so that students can walk with a maximum conscience to receive the sciences 
transferred from teachers with the obtaining the maximum value of their students in the classroom. A small number of students in the classroom are likely to be motivated by some small;

- $\quad$ The process of study in the classroom operates normally.

- $\quad$ Students can understand the materials that teachers think.

- $\quad$ Students can do it independently.

- $\quad$ Give ideas to the students so they can help each other in the classroom with materials.

- $\quad$ Through the motivations of the teachers, students can also be valued and understood as many".

Source; (Interview on Monday, 19 October 2020)

In the second interview with the Deputy Coordinator of the school curriculum, Mr. Hermenegildo Sousa, B.ETT

In your opinion, whether the role and motivation of a teacher is important to students?

The motivation of the teacher for the students in the learning process is very important because it is motivating the education process of teachers to students in the learning process to ensure the success of future generations. The motivation of students is important for teachers to motivate students to be creative in the classroom and the consolidation of science, to improve the quality of education and the form of human resources. The importance of motivating students in the learning process is to clarify some of the following points:

- Motivation is a guide or a teacher to educate students.

- Student studies are a fundamental basisfor teachers in the learning process or learning process.

The motivation of the students is a meeting to consider and measure the students' knowledge and".

Source; (Interview on Monday, 19 October 2020)

\section{What motivates students to learn?}

"The motivation of the study for the students in the learning process in the classroom has been a good example because it is motivated by teachers and has had a good collaboration with the students and teachers in a clear method or motivating and explanation. The motivation of the study for the students in the learning process may increase the creativity of students in obtaining material and listening to what teachers teach in the classroom, the teacher always uses many strategies so that students can understand and understand what they are going to learning.

The Motivation of studies for students conducted by teachers in the learning process is as follows:

- Study approach to students.

- Contribute the students to follow the international regulation.

- Have students learn hard in the learning process or at home.

- Make criteria for each student before they value each Student

Source; (Interview on Monday, 19 October 2020)

How is the learning management process in classrooms and workshops?

"The management of learning in class always runs well because currently it is in accordance with the existing lesson plans according to the predetermined school schedule. The teacher always uses the right strategy to teach students well so that they can know and understand what the teacher teaches in the class so that the teacher can manage the class well and use the right method to understand the characteristics and knowledge of the student. There are important points for teachers in managing the learning process, namely as follows: classroom management, student approaches. Student incapacity, maturity, or punctuality. According to schedule, or lesson plan".

Source; (Interview on Monday, 19 October 2020)

\section{What methods are used in the learning process?}

"The method is a strategy used by teachers for the transfer of science that they have for students in the learning process. Some methods are usually used to increase student capacity are as follows:

- Accretion method.

- Explanation of teaching materials in the classroom.

- $\quad$ The lecture method for students in the classroom.

- The method demonstrates that: show an example or show something that relates to the students' material so they can understand.

- Student joint methodology to be effective and efficient in learning processes.

- $\quad$ The method of approaches the students or approach the students to understand the students' characteristics and weaknesses.

- $\quad$ The method of asking and responding to the students and teachers of the class.

- $\quad$ The assessment method for students is to value the learning and learning outcomes.

The method mentioned above is that teachers are used to increasing their students' capacity in the learning process and know the students' thoughts in the classroom and how to motivate them to increase their students' capacity, knowledge, knowledge, skills, personality, and intelligence to responsibility for their own lives in the future. Source; (Interview on Monday, 19 October 2020)

In your opinion, how is the learning process in classrooms and workshops?

"The reality is that the students in the classroom always go smoothly, even if students sometimes have a com motivation in the classroom, they should always call them or approach them to encourage them to refrain from interrupting other students who are interested in learning something. Teaching in the classroom is also calm because teachers have strategies to form students noise or lack of awareness, moral personality is always the teachers who approach them so that they can change their behavior.

\section{Source; (Interview on Monday, 19 October 2020)}

\section{How do you motivate your students in classes and workshops?}

"Students' motivation in school is always good because teachers have strategies and teaching methods that are based on the teacher's planning, knowledge and experience so that they can be implemented in the classroom normally and calmly. Motivation of students in the classroom so that students can be respected and full of knowledge and morals, as educators have a responsibility to help and motivate students to study and study science and technology to develop their knowledge. As well as motivating students in the class to increase their capacity and knowledge so that they become quality education personnel and intelligent and adaptive human resources.

Source; (Interview on Monday, 19 October 2020)

In the third interview with the Technical Support Office (GAT) and Mr. Duarte Da Costa, L. Eng

In your opinion, is the role and motivation of a teacher important to students?

"The role of teachers and motivations of teachers for students is very important because they are teachers (educators) must have the maximum responsibility to provide the students with appropriate 
protection in the learning process activities so they can open their minds and content to gain and consume the sciences that come from school teachers. As teachers in technical schools, the role and motivation are the main actions that should be delivered or demonstrated to the students because technical students face learning processes in both parts of the theoretical theory, including general materials and practice in each department. The role of teachers and teacher motivation for the students through positive behavior of teachers and how to joint students so they can follow the same internal school regulations:

- Student guide to be an effect and efficiency in learning processes.

- $\quad$ Student absenteeism is understood to be valued in learning.

- A student is a person who has high moral education and is responsible for himself. The student was motivated to diligently study so that this is a human resource full of a spirit of nationalism to achieve the goals and expectations of a dignified future.

Source; (Source: Interview on Monday, 19 October 2020)

\section{What motivated the students to study in the learning process?}

"The motivation of the school students went well and the teachers used different strategies in learning so that students can understand and know what their teacher is teaching in the classroom. The motivation of the students is an important aspect of the teacher transmitting information or science to students in the learning process to empower them in the education sector that is necessary for human needs and to be people with quality education and human resources capable of doing something in their lives and developing their capacity to increase their knowledge, skills, and skills.

The motivation strategy used by the teacher is as follows:

- $\quad$ This can be done through lesson plans and materialization domination.

- $\quad$ This can be done through approximation.

- $\quad$ This can be done through explanation, description of the subject matter, or subject matter to study. Tell students to be happy to actively participate in the learning process.

- $\quad$ Ask questions (feedback), provide work, and discuss.

- $\quad$ Practice or test the students' understanding.

- Conduct an assessment or procedure for students to understand the students' knowledge of science that is taught in a classroom or where students learn from.

Source; (Interview on Monday, 19 October 2020)

How can the learning management process in the classroom and workshop?

"The learning management process in the classroom focused on student punctuality or discipline in the classroom and controls the students in the learning process. The management of teaching in the classroom is based on student plans and teacher manuals so that teachers can teach under the school curriculum. The correct process in the classroom is that the teachers have to control students' material and manage classes. The learning management process in the classroom is: Explanations, ask students' understanding. Allow students to give time to provide feedback, student responses, discussion and practice, Based on the hours that are completed in the curriculum and based on lesson plan".

Source; (Interview on Monday, 19 October 2020)

What method can you use in the learning process?

"There are many methods that you use to motivate or increase your students' capacity because the teacher is an example for the students and the students in the classroom. They are the methods: Discussion, Explain (in theory and practice), Write, Work (in theory and practice), lecture. "In my opinion, I consider the students' learning process in this school because most teachers use a range of methods to motivate students and students to also understand the objective of the topic that teachers teach; Motivation of good students, the discussion of the subjects that students received, the presentation of labor, the teachers use the appropriate method to attract students so that they do not feel comfortable, relaxing and others in class until they finish their studies.

Source; (Interview on Monday, 19 October 2020)

\section{What motivated students to study in the classroom and workshop?}

"The Motivation of studies for students in the learning process I felt better and the students were able to understand what the teacher was teaching in the students' study process in the classroom and had a workshop in their workshop. The result was to encourage the students to work well, The students can understand the subjects that teachers teach, the students can do the exercises that are given by teachers, the discussion among students has positive results, by motivating the students to study themselves and understand many of them.

\section{Source;.( Interview on Monday, 19 October 2020)}

In the fourth interview with student Affairs and Mr. Faustino Simões Carvalho, S.Ag whether the role and motivation of a teacher is important to students?

"The role of teachers and the motivation of the teachers in the learning process is very important and it is a good activity for teachers because it is motivating teachers to enter the teaching process, motivating students in the learning process for reasons to bring students with knowledge and students to understand the lives of others in the school, family, society, community and other places.

The reasons for teacher role and motivation for study are as follows:

- To show and motivate students to understand their respect and ethical ethics.

- Through doing a good role and motivating students is a meeting to consider and measure the students' knowledge.

- Think about the students so that they can also think about how to be a good student and can achieve a successful goal.

- As a regulation that gives good influence to the students to avoid any behavior that does not benefit themselves

Source; (Interview on Tuesday, 20 October 2020)

\section{What motivated the students to study in the learning process?}

"As a student's observation has so far been about the motivations of the student's study in the learning process, as students have previously been motivated by the informal motivation that was from the home before coming into the classroom, and then in the classroom, there were some motivations from the heads of department to put them into practice during the learning process. On the other hand, it is also intended to benefit teachers and students in this school, especially during the learning process because they always work together and have good collaboration between them. student issues often encourage students, particularly how to show good behavior during the entire learning process in this school when meeting with all teachers, how they prepare themselves to become quality technical students to achieve individual goals and demands in the future.

\section{Source; (Interview on Tuesday, 20 October 2020)}

How can the learning management process in the classroom and workshop?

"According to my observation of the learning management process in this school, we review each subject because there are some matters that walk with theory (for example, general materials) and 
in some matters walkthrough theory and practice (materials of department or usually call on productive matters) so that students can regularly remember that the duties of students in ESTVGBERA should be mandatory to follow the internal school regulations so that they can proceed with the proper learning process. The effective learning management process in the classroom is discipline and maximum control which means that the strengthening of good cooperation between teachers and students in the classroom and doesn't have any thought to benefit other students in class.

The learning management process in some classes is as follows:

- Enter to a schedule that is valid according to the school curriculum.

- Don't noisy in your classroom.

- Give time for students to give their feedback, student responses are problematic.

- Discussion, practice, based on hours ending in the circle.

- $\quad$ Based on the lesson plan. (Source; (Interview on Tuesday, 20 October 2020)

\section{What method do you use in the learning process?}

"The method used by teachers in the learning process is similar to other teachers even though there are some differences in department subjects and some materials from the general department but with the main objective is to bring students into the technical environment to compete with others in the labor market, for this reason, the teachers use a clear, thorough explanation method and a reality in terms of the technical area. The learning process in the classroom is positive because teachers and students are committed to collaborating in the classroom, teachers play a role that is committed and aware about teaching students (the transfer of science and technology) so that students can develop their ideas to achieve the results of their learning activities and achieve this goal. Source; (Interview on Tuesday, 20 October 2020)

In your opinion, how is the learning process in classrooms and workshops?

"According to my opinion, the process of teaching in the classroom is very good because most teachers use different methods based on their experiences, so they can attract and motivate students to understand the science that is more motivated by good motivation, presentation exercises, discussion of lessons learned and others. Source; (Interview on Tuesday, 20 October 2020)

What motivated the students to study in the classroom and workshop?

"The motivation of the study students in the classroom is good and parents at school always motivate students to be more creative and make students better understand what students don't know. these reasons are the main causes of;

- Show the way to succeed in the future for students.

- Making students more creative, smarter, and with the highest quality of knowledge in the technical area.

- Students can be valued by motivating students". Source; (Interview on Tuesday, 20 October 2020)

In the fifth interview with Mr Ilidio Do Ceu,

How Do you think the role of teachers and the motivations for your students is important?

"The role of teachers and teacher motivation for students in the learning process is very important for all teachers because it is through the role of the teacher that gives them ideas to determine the quality of their studies in the technical field and motivation is the key to education. process for students in the learning process to ensure their success in a more prosperous future. Student motivation is important for teachers to motivate students to be creative in theory, practice, and scientific strengthening in order to improve the quality of education and the form of human resources.

The importance of motivating students in the learning process, namely the clarification of some of the following points:

- Motivation is a guide or a means for teachers to educate students.

- The student study is a fundamental basis for the teacher in the learning process or learning process.

- The motivation of the students is a meeting to consider and measure the students' knowledge".

Source (Interview on Tuesday, 20 October 2020)

\section{What motivated the students to study in the learning process?}

"I want to add that the motivation to study students in the classroom is very good and the teachers always motivate them to be more creative and make students understand what they have not learned and that these motivations are like; Show the way to the students, make students creative and become even more mature, The students can value themselves through the motivation of the teacher, the students' understanding well". Source (Interview on Tuesday, 20 October 2020)

How is the learning management process in classrooms and workshops?

"The teaching management process in the classroom is focused on the punctuality or discipline of students in the classroom and controls students in the learning process. The management of teaching in the classroom is based on lesson plans that guide teachers to teach according to the school curriculum. The proper learning process in the classroom is to control students' discipline and manage classroom management, how they can receive subjects, and serve teachers in the classroom. Several factors that are used for the management process in the classroom, namely the following: Explanations, ask students to understand, Give time for your feedback, problems, discussion, practice, Based on the hours of the lesson plan and the classroom plan". (Interview on Tuesday, 20 October 2020)

\section{What method do you use in the learning process?}

"There are many methods that you are using to motivate or increase your students' capacity because the teacher is an example for the students and the students, and they also follow what teachers show and methods are: The description method in the classroom, the explanation method for students, the method of teaching materials and making an example to the students, the sabotage, Ask students to understand the subjects that the teacher is teaching in the learning process, the procedures or evaluation of students to value their students and the learning process". (Interview on Tuesday, 20 October 2020)

According to the teacher, how did the teaching process in the classroom and the workshop?

I think about the learning process in this school because most teachers use different methods to motivate students to understand the material taught by the teachers; the Motivation of the students, the discussion of the subject matter, the teacher's work, and the method to attract students very well". (Interview on Tuesday, 20 October 2020)

How can the learning management process in the classroom and workshop?

"I know during the exercise of the duties as a teacher in ESTVGBECORA DILI, the motivation for the study in the classroom and this workshop is very necessary because technical students should 
have good instructions or guidance so they can be a creative and innovative student.

These reasons were as follows:

- Instruct students before instructing them to do their job.

- Practicing practice based on student capacity.

- Valuation of work by improving

- Be patient with the students through good communication.

- Make their knowledge known through the maximum explanation ".

(Interview on Tuesday, 20 October 2020)

\section{In the sixth interview with Mr. Jose Simões, S.Ag}

How do you think the role of teachers and the motivations for your students is important?

"The motivation of the student is very important because it motivates students to bring students and transform their personality into a dignified person. The motivation of students is important because they learn what is good and understand and value in their lives. Students motivation to have the capacity to solve problems in their lives and to comply with domestic and external laws or regulations. The motivation of the students is through many ways because all students have different characteristics and teachers have a good understanding to motivate students on the right path and help them to become people full of intelligence and as citizens who aspire to a good future". (Interview on Tuesday, 20 October 2020)

\section{What motivated the students to study in the learning process?}

The motivation of the students during the learning process is always calm because students have the moral discipline to listen and accept what their teacher is teaching and explained in the classroom. The motivation of the school students through some aspects that teach students to gain understanding. The lessons used to motivate the students are as follows:

- The Contains motivation to disobey. the motivation of students in general to prove international discipline.

- Guide the student to learn about the school environment and learn how to study.

- Study the characteristics of each student.

- Motivates the student according to the personality of the instructor.

- Motivates the student to be effective and efficient in class.

- Student motives to maintain calm and respect for other instructors and dignity."

(Source: Interview on Tuesday, October 20, 2020)

How is the learning management process in classrooms and workshops?

"The learning management process in the classroom is focused on student punctuality or discipline in the classroom and controls the students' learning process. The management of teaching in the classroom is based on lesson plans that guide students and teachers so that they can teach under the school curriculum. The proper learning process in the classroom is to control the discipline of students and manage the classroom, how they can receive the materials, and answer the teachers in the classroom. several factors that use the management process in the classroom, namely the following: Explanation, ask students' understanding, Be time for your students' feedback, problems, discussion, practice, Based on the hours of the lesson plan and the classroom plan".

(Source: Interview on Tuesday, 20 October 2020)

\section{What method do you use in the learning process?}

"The method used in the learning process is that teachers enter the classroom must always show a dignified personality and have the maturity of educators. The method used in the learning process is the method of description, explanation, lecture, approaches, guidance, joint student control, classroom control, and method used by these teachers in the learning process to give students the subject of subjects or teaching. The method used by the teacher is as mentioned above and is clarified below:

- $\quad$ Lesson plan, student control, and management classroom so that students can be effective and efficient in attendance.

- Methods of discretion, explanation, for the subject matter that teachers teach in the auction.

- The lecture method so that students can understand the motives of learning.

- the Section asks and answers the students and teachers about teaching materials.

- Keep procedures or evaluation of each student in the learning process".

(Source: Interview on Tuesday, 20 October 2020)

According to the teacher, how did the teaching process in the classroom and the workshop?

"The teaching process in the classroom is positive because the teachers and students are committed to collaborating in the classroom so that the learning process can be peaceful and effective and effective in the classroom, following the subjects and learn together with the teachers in the classroom. Teachers always have a commitment and awareness to teach students to learn science and technology so they can develop their students' thinking to achieve learning outcomes and achieve their expectations, teachers and students' expectations.

(Source: Interview on Tuesday, 20 October 2020)

\section{What motivated students to study in the classroom and workshop?}

"The interest of the students in the classroom is always good because the teachers have strategies and teaching methods that are based on their teacher's lesson plan so they can have a normal and quiet learning process. The Motivation of students in the classroom so that students are respectful and full of moral education, as educators have the responsibility to help motivate students to study hard and learn science and technology to develop their lives. And motivated the students in the class to increase their capacity and knowledge so that they can become people of good quality education and human resources full of intelligence for the development of their lives".

Source (Interview on Tuesday, 20 October 2020)

Based on the above statement it is written that: Student mobility in classrooms and workshops is very important for teachers so that students can have skills and knowledge and bring students to learn something in their lives and transform their lives into a spirit of nationalism that serves the community, the Church and the needs of the State. Student motivation in the classroom becomes the basis for teachers to know the characteristics of each student, motivating students to have a moral personality that respects social life. Regarding the informants' answers, the results of the study indicate that student motivation in classrooms and workshops is very important to ensure maximum teacher attendance and through this motivation becomes one of the main skills to empower students. in the technical field. The results of the analysis of the informants' answers to the first question indicate that the role of the teacher and student motivation is very important because it is a useful guide for students during their studies at THSV-GIBECORA DILI and completes their studies in the future. The response to the second 
question from all informants was that student motivation in the learning process is a measure of teacher behavior and understanding of student behavior and can change minds so that they can learn better and become quality students from THSV-GI BECORA DILI and in the community. Based on the information provided by the informant about the management process at THSV-GI BECORA DILI, the owner wrote to conclude that management in schools is running well because they work together between teachers and students in classrooms and workshops, following internal school regulations, departments, and teachers at each subjects. The results of the analysis of information writing are the methods used by teachers based on experience, knowledge, each teacher, and how they use good methods so that students understand the material taught by each teacher in their area. In fact, in the THSV-GI BECORA DILI school, the learning process is separate in two parts, namely in the theory room, this activity refers to general material and several departments and learning activities that can be carried out in workshops of each department, sending students to practice school facilities according to subjects. And the process of implementing learning activities runs normally because it follows the existing curriculum and is in accordance with the school's internal regulations.

Research Implications: The implication of the research results consists of historical implications and practical implications.

Theoretical Implications: The teacher role is a guide for all students who have conducted their studies at Technical High Schools Vocational-Group of Industry, THSV-GIBecora-Dili, so that they can participate as technical students with the quality compared to other school students. The Motion of study has a major bearing on the results of the student study meant that students who study hard produce good and qualified results. On the other hand, the motivation for the study can increase the will of the students who have the minimum value so that they can continue to study more and to compete with other colleagues who have the maximum value, and therefore ask the teachers to continue to motivate their students at any time to achieve their objective. The Dau-day, despite the student study interaction, has not yet been as teachers, always have good relations with the students in the learning process so that they can solve the difficulties students face in the process of theory and practice in that school.

Practical Implications: The result of this research on the role of teachers and the motivating of teachers in the learning process is a key suggestion for teachers at Technical High Schools Group Vocational-Group of Industry, THSV-GIBecora-Dili, to improve student capacity and improve quality studies.

\section{CONCLUSION}

Based on the results of the research carried out to describe here, the following are written conclusions based on the following research findings:

- The role of teachers and teachers in the learning process is very important for teachers and teachers before being taught in the classroom, using the motivation to be a way for teachers and teachers to ensure the quality of learning in the classroom, motivate students to consume information or science that teachers and teachers teach in the classroom.

- b. Encouraging students in the learning process is very important for teachers and teachers in the learning process, so they can bring students the knowledge and know the motive of their studies in the school environment.

- The role of the teacher is to encourage students in the learning process as guidance provided by teachers and teachers so they can continue to trust together between teachers and students to ensure they can find solutions to the difficulties and challenges that students face as active students in the ESTVGBECORA DILI.
- Another part of the role and motivation of the teacher, there are also methods of teaching and internal regulation of the school curriculum based on the technical school curriculum, so that students can continue to strengthen their will in the school and bring students to achieve their goal according to the capacity of technical science to individuals and to a group within the community.

Suggestion : Noting the above conclusions, the authors ask all components that have the competence to handle and prioritize as follows;

- To BECORA DILI THSV-GI teachers, it is necessary to improve the strategies and conditions of teachers to motivate students to be creative in learning, as well as moral discipline processes, according to the curriculum, to improve the quality of education in the future.

- $\quad$ For the State of Timor Leste, especially the Ministry of Education, with all directions pay attention to and prioritize all factors that ultimately have an impact on teaching methods in the learning process to ensure the quality of education, especially in the technical field of Timor Leste. -Leste and can compete in the labor market.

\section{REFERENCES}

A.M, Sardiman (2007). Interaksi dan motivasi belajar mengajar, Jakarta : PT: Raja Grafindo Persada.

Hamalik, Oemar, (2011). Kurríkulum dan Pembelajaran, Jakarta : Bumi Aksara.

Disionáriu Nasional ba Tetun Ofisial, (2005:42). edisaun ba dahuluk. Instituto Nacional de Linguistíca : INL-UNTL

Lexy. J. Moleong, (2007). Métodu Penelitian Kualitatif. Bandung : Remaja Rosda Karya.

Hamdani, (2011). Strategis Belajar Mengajar. C.V. Pustaka Setia.

Aunnurhman.2009. Belajar dan Pembelajaran. Bandung : C.V.

Disionáriu Boot Dalen Indonesia (1996:75)

Azhari, Akyas. 1996. Psikologi Pendidikan, : Semaranag Dina Utama Semarang

Daradjat, Zakiyah, 2000 Ilmu Pendidikan Islam, Jakarta Bumi Aksara,.

Departemen Pendidikan dan Kebudayan, 1999. Kamus Besar Bahasa Indonesia, Jakarta : Balai Pustaka.

Nasution, S.2007. Didaktik Asas-asas Mengajar. Jakarta : Bumi Aksara

Djamarah, Syaiful Bahri. 1994 Prestasi Belajar dan Kompetensi Guru,

Purwanto M, Ngalim. 2009 Psikologi Pendidikan, Bandung : Remaja Rosda Karya

Pedoman Ilmu Jaya, Salim, Peter. 1991. Kamus Besar Bahasa Indonesia Kontempurer, Jakarta : Modern English

Syah, Muhibbin. 2008. Psikologi Pendidikan dengan Pendekatan Baru. Bandung Remaja Rosdakarya.

Sabri, M. Alisuf, 2001. Pengantar Psikologi Umum dan Perkembangan, Jakarta : C.V.

Sardiman, A. M, 1990. Interaksi dan Motivasi Belajar Mengajar, Jakarta : Rineka.

Soemanto, Wasty, 1990. Psikologi Pendidikan, Landasan Kerja Pemimpin Pendidikan, Jakarta : Rineka

Konstituisaun-RDTL artigu 59 kona-ba (Edukasaun no Kultura)

Diploma Ministerial Nú 22/2016 9 de Março 